\title{
Embodied cognition in 'black metaphors': the BAD IS DARK metaphor in biblical texts
}

\author{
Cognição corporificada nas "metáforas negras": \\ a metáfora MAL É ESCURIDÃO em textos bíblicos
}

Solange Vereza

Universidade Federal Fluminense - UFF

\section{Raquel Puente}

Instituto Militar de Engenharia - IME

\begin{abstract}
Recent studies on metaphor have focused on the ideological dimension of the conceptualization of experience and its realization in discourse. Within this perspective, racism has been approached as the driving ideological force underlying the conceptual metaphor BAD IS DARKNES, which would license what has been referred to as 'black metaphors'. The aim of this paper is to investigate an alternative hypothesis - without rejecting the ideologically-based one - to approach black metaphors, from the perspective of the sensorimotor experience with darkness. The analysis looks firstly into passages of biblical texts, where the literal markers of the source domain are found, in order to investigate how physical experiences with darkness are evaluated in the narratives. Secondly, the metaphorical uses of the same expressions and their target domains are identified. The results have confirmed the possibility of the conceptual projection from the sensorimotor experience with darkness onto negatively evaluated abstract notions.
\end{abstract}

Keywords: Black Metaphors. Cognition. Sensorimotor experiences. Biblical texts

Resumo: Tendências recentes nos estudos da metáfora têm focado na dimensão ideológica da conceptualização da experiência e de sua manifestação no discurso. Nessa perspectiva, o racismo é abordado como a força ideológica subjacente à metáfora conceptual MAL É ESCURIDÃO, que licenciaria as chamadas "metáforas negras". O objetivo deste trabalho é investigar uma hipótese alternativa - sem rejeitar a hipótese ideológica - para se abordar as metáforas negras, a partir da perspectiva da experiência sensório-motora com a escuridão. Essa hipótese é explorada através de uma investigação das "metáforas negras" encontradas em textos bíblicos. A análise investiga, primeiramente, passagens de textos bíblicos em que são encontradas marcas consideradas literais do domínio-fonte, a fim de investigar como experiências físicas com a escuridão são avaliadas nas narrativas. Em segundo lugar, os usos metafóricos das mesmas expressões e seus domínios-alvo são identificados. Os resultados confirmam a possibilidade da projeção conceptual da experiência sensóriomotora com a escuridão em noções abstratas, avaliadas negativamente.

Palavras-chave: Metáforas negras. Cognição. Experiências sensório-motoras. 


\section{Introduction: 'black metaphors'}

When someone uses the expression, in Portuguese, 'a coisa está preta' (which can be literally translated as 'things are black', meaning that a particular situation or context is evaluated as being highly negative), they do not realize that this negative evaluation would be anchored by a conceptualization, also of a negative character, of the very colour black and its socially constructed connotations.

In English, the concept of 'black', and the linguistic terms related to this concept, seem to invoke similar negative evaluations. An informal contest promoted on the Yahoo Answer Web page ${ }^{1}$, for example, the challenge proposed was: "First person to get 10 or more metaphors for the colour BLACK... gets best answer...". The answer considered the best one was the following: The colour black is...

...the cold, dark heart of a maniacal serial killer.

...a reflection of the deepest reaches in an underground cavern.

...the stark realization of great potential finally and permanently squandered.

.... lonely shroud of hopelessness.

....a thick, cold, suffocating blanket.

...the remorseless eyes of depravity.

...the gun of a ruthless assassin.

...a promise of nothing but bleakness and emptiness forever.

...a light-eating hole in the stomach of the universe.

...a life devoid of any redeeming honor.

.... lifetime spent fighting and hating your enemy

The question which emerges from these examples is why a negatively evaluated situation is often associated with the colour black, in Portuguese, in English and, as it might be speculated, in other languages. In Cognitive Linguistics, associations like this are seldom considered a random or arbitrary phenomenon: they are believed to be conceptually motivated.

Within this perspective, this connotative metaphorical association has been approached as a form of discrimination against 'black communities' (a possible prejudicial metonymy for the 'African race') entrenched in language through the so-called 'black

<https://answers.yahoo.com/question/index?qid=200902181350 54AAmuQ6H>. Access in 3 Jun. 2017. metaphors' (PAIVA, 1998). Although it is possible that no discrimination is evoked intentionally, or even consciously, in the use of the expression 'a coisa está preta', in other expressions such as 'um preto de alma branca' (a black person with a white soul), a racist ideology seems to be far more evident. This seems to be the case of highlighting, or just mentioning, the skin colour/race of a person when this supposed attribute is obviously unnecessary to refer or even to identify the referent. An example of the latter case is the use of the expression "um negro de primeira linha" (a first class black man) used by Supreme Court Minister (Brazilian STF) José Roberto Barroso, to refer to exSTF's Minister Joaquim Barbosa. After criticisms from some segments of the Press and anti-racism activists, the Minister apologized:

I expressed myself in an unfortunate way and used the expression "negro de primeira linha". There are no whites or blacks of "the first line", because people are equal in dignity and rights, deserving the same respect and consideration. I would like to apologize to people whom I may have offended or hurt with this unfortunate statement. I would like to apologize, especially if, unintentionally and unconsciously, I have reinforced a racist stereotype that I spent my life trying to fight and defeat ${ }^{2}$.

By saying that his "unfortunate" statement was "unintentional" and "unconscious"- which, according to his well-known history in defending civil rights, might well be true - the minister is confirming the ubiquity of ideology and the way it is entrenched in language. The use, therefore, of idiomatic/formulaic expressions, many being highly conventionalized metaphors, which evoke an association between the black colour and semantically related terms, such as escuro (dark), preto (black) and negro, which highlight negative aspects of a situation, phenomenon, object or even

\footnotetext{
2 Manifestei-me de um modo infeliz e utilizei a expressão 'negro de primeira linha'. Não há brancos ou negros de primeira linha porque as pessoas são todas iguais em dignidade e direitos, sendo merecedores do mesmo respeito e consideração. Gostaria de pedir desculpas às pessoas a quem possa ter ofendido ou magoado com essa afirmação infeliz. Gostaria de pedir desculpas, sobretudo, se, involuntária e inconscientemente, tiver reforçado um estereótipo racista que passei a vida tentando combater e derrotar" Disponível em: http://g1.globo.com/politica/noticia/barroso-pede-desculpasapos-chamar-joaquim-barbosa-de-negro-de-primeiralinha.ghtml>. Acesso 9 Jun. 2017. Fala integral disponível em vídeo em: <https://www.youtube.com/watch?v=dEahyE2fGyU>.
} 
people, may fall into the same category: unintentional and unconscious language instantiations of racism.

Recent studies on metaphor approach this phenomenon as a mapping from one domain of experience (colour) onto another, of a more abstract nature. The terms and expressions mentioned above are considered part of a set of linguistic markers known in the literature as "black metaphors", which would convey, reproduce or even reinforce a racist ideology. This view has been put forward and elaborated by Paiva (1998), and, so far, its central argument has not been challenged or problematized in the literature on metaphor.

The present paper has as its main objective to question the generalizing explanatory power of this view, namely that black metaphors would evoke and reproduce a racist ideology. On the basis of the awareness, on the part of many language theoreticians (e.g., MUSOLFF, 2012), of the sociodiscursive character of language and hence of the historically constructed discriminatory attitude towards African communities, resulting of socioeconomic processes of domination, the "racist hypothesis" as an explanation for black metaphors is not easy to be challenged.

However, we believe that, without rejecting the ideologically-based hypothesis, and, supported by the postulates of 'embodiment' defended by Cognitive Linguistics, it is possible to explore an alternative (in the sense of being complementary, not substitute) hypothesis: that there would be another motivation, of sensorimotor basis, for the emergence of at least some of the black metaphors found in language. Thus, one cannot rule out the possibility that expressions like "the thing is black" (or dark ages, in English, for example) may have been conceptually motivated by concrete bodily experiences with the darkness, and not solely by sociocultural factors, like racism.

In this article, the hypothesis regarding the bodily basis of black metaphors, or at least of some of them, is supported, theoretically, by the notion of 'embodied cognition' (JOHNSON 1990; LAKOFF; JOHNSON, 1999) and, empirically, by a corpus analysis of black metaphors found in biblical texts, or, more precisely, the electronic version of the Old Testament. The choice of biblical texts as the corpus of this study is justified, firstly, by the results of a preliminary pilot analysis, through which many metaphors from the domain of "darkness"- and of its opposite concept "light"- were identified. This analysis, though still theoretically uninformed, seemed to corroborate what Kittel and Friedrich (1971) suggest:

\begin{abstract}
The term 'darkness' in the Bible is rarely used in its optical sense, but darkness experienced as an enveloping sphere and described in its significance for existence, i.e., as a hindrance to movement and action, for foresight, as the sphere of objective peril and subjective anxiety. It also has a connection with blindness (Acts 13:1), (Acts 13:11), ungodliness or immorality (John 3:19), evil (Luke 22:53), death (Matthew 4:16) and even hell (Jude 13). (KITTEL \& FRIEDRICH, 1971, p. 123)
\end{abstract}

A second reason for choosing this particular corpus was the fact that racial discrimination, though clearly present in biblical times (unequal treatment of Israelite vs. non-Israelites slaves, for example) did not seem to be so directly associated with skin colour as it has been in the last centuries. Finally, the operational possibility of conducting an electronic word search in a digitalized corpus facilitates the identification (and quantification) of linguistic metaphors and their context of use.

\section{Sensorio-motor experiences with darkness}

A major focus of Cognitive Linguistics is the role of human experience in meaning construction, and the centrality of the body, in its sensorimotor dimension, as part of this experience. For Lakoff and Johnson (1980 [2002]), this "bodily anchor" interacts with the mind in the conceptualization of experiences, hence the metaphor projections from the more basic and concrete domains (source domains) onto more abstract ones (target domains).

In Grady's studies on primary metaphors (GRADY, 1997), emphasis is given to the interaction between the human cognitive apparatus and sensorimotor experiences as a generator of 
metaphoric associations. For the author, the repetition of strongly correlated experiences of different nature (sensorimotor and cognitive), such as lifting objects and the perception of the difficulty or ease of raising them, establishes a strong correlation between these different domains: the physical/concrete and the abstract. This is what motivates the conceptualization of more abstract concepts (difficulties), in terms of a more concrete one (weight), leading to the primary metaphor DIFFICULTY IS WEIGHT. The recurrence and regularity of simultaneous activation of neural networks in the brain responsible for sensory-motor experiences would set particular connections, of which we have little or no awareness, nor control.

The embodiment thesis is indeed more evident in the case of primary metaphors; however, it transcends it, as:

many features of cognition are embodied in that they are deeply dependent upon characteristics of the physical body of an agent, such that the agent's beyond-the-brain body plays a significant causal role, or a physically constitutive role, in that agent's cognitive processing ${ }^{3}$.

We, thus, understand the world, especially the 'abstract world', through metaphors that emerge from our bodily experiences. Cognitive mechanisms would then be entrenched in sensory perceptions, shaping, thus, our conceptual system. Reason, therefore, would not be something that would transcend our body: it is also 'embodied', since "it stems from the nature of our brain as well as from the peculiarities of our bodies and the experiences in the world we live in" (VEREZA, 2001, p. 169). The experientialist approach to the formation of our conceptual system and to the language motivated by it emphasizes the importance of sensorimotor experience as a determinant factor in the very emergence of this system. In Philosophy in the Flesh (1999), Lakoff and Johnson define the "embodied mind" as follows:

Reason is not disembodied, as the tradition has largely held, but arises from the nature of our brains, bodies, and bodily experience. This is not just the innocuous and obvious claim that we need a body to reason; rather, it is the striking claim that the very structure of reason

\footnotetext{
${ }^{3}$ Embodied Cognition: Stanford Encyclopedia of Philosophy, 2015.
}

itself comes from the details of our embodiment. The same neural and cognitive mechanisms that allow us to perceive and move around also create our conceptual systems and modes of reason. Thus, to understand reason we must understand the details of our visual system, our motor system, and the general mechanisms of neural binding. In summary, reason is not, in any way, a transcendent feature of the universe or of disembodied mind. Instead, it is shaped crucially by the peculiarities of our human bodies, by the remarkable details of the neural structure of our brains, and the specifics of our everyday functioning in the world." (LAKOFF; JOHNSON, 1999, p. 4)

In the specific case of concrete experiences with the night, it is fairly common to find children who are afraid of the dark and even adults who feel rather uncomfortable with the lack of light. When we are faced with an unfamiliar environment, at night, we have feelings of discomfort, insecurity, vulnerability and even fear; darkness affects our sight, hinders movement and the identification of people, colours and objects. Scientists at the University of Southern China (LY I et al., 2015), after conducting psychological experiments, have concluded that the fear of darkness has evolved in humans through the association between night and darkness. In other words, darkness itself has only become a source of discomfort because it represents what it is bodily experienced during the night or in any environment without light. Regardless the metonymical association which seems to exist between darkness and night, what is relevant to our present inquiry are the feelings of anxiety, fear or simply discomfort triggered by the physical experience with the dark, which may be projected or mapped onto negatively evaluated abstract domains. We propose that this mapping anchors the primary metaphor BAD/EVIL IS DARK, which, in turn, would licence many of the so-called 'black metaphors'.

Although it is widely known that colours do not exist objectively in the outside world (LAKOFF and JOHNSON, 1999), there is a widespread belief that people tend to associate colours with the sensory motor perceptions triggered by them, and these perceptions, in turn, define our experiences with colours. Therefore, when we say that the absence of 
light is represented in our minds by the colour black, we embed on the experience with the dark the various meanings of the black colour, consolidated by time and by repeated experiences.

According to Guimarães (2000), colour itself is a kind of information that should be "perceived, decrypted by sight, interpreted by our cognition, and also, transformed into updated information". (GUIMARÃES, 2000, p. 15). In this sense, besides the fact that colours are related to our colour memory, their meanings are also shaped and transmitted by language and culture. Consequently, we can say that colour does not have symbolic autonomy, i.e., it is delimited by "symbolic and historical values rescued by a given context”. (ibid., p. 2).

Considering this 'symbolic value' with reference to the colour black and its association with the concreteness of the night / darkness context, it might be supposed that the negativity of the bodily experience with the darkness is also transferred to abstract notions. The memes in figure 1,2 and 3 illustrate some uses of 'darkness' (as absence of light) as the highlighted element in the source domain, mapped onto negatively evaluated abstract target domains: lack of hope, ignorance and hate.

\section{Figure $1^{4}$ : darkness as lack of hope}

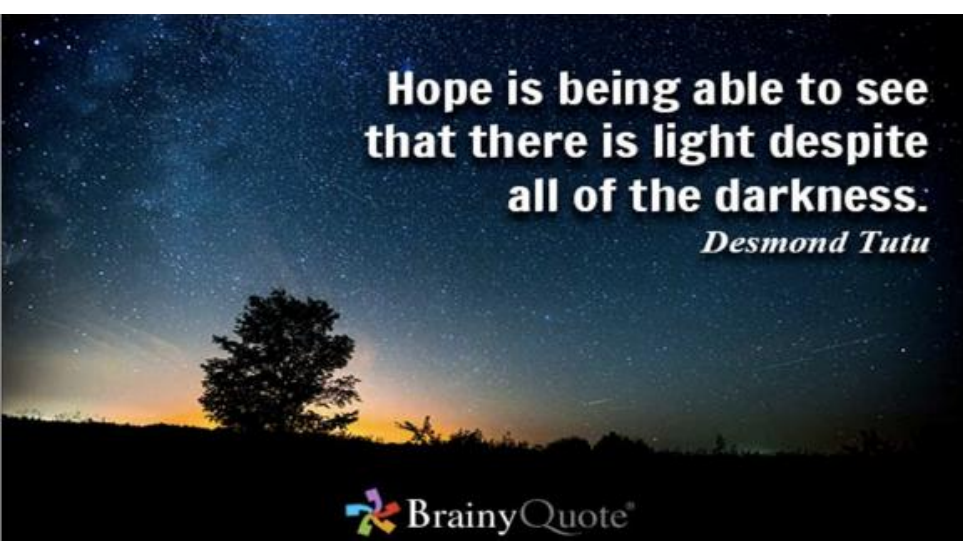

${ }^{4}$ https://www.brainyquote.com/photos/d/desmondtutu454129.jpg

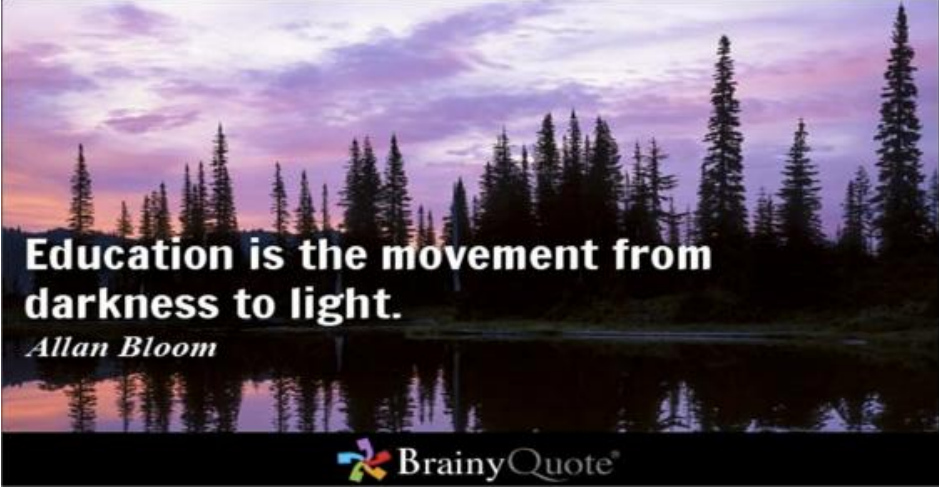

Figure $2^{5}$ : darkness as ignorance

\section{Darkness cannot drive out darkness; only light can do that. Hate cannot drive out hate; only love can do that.}

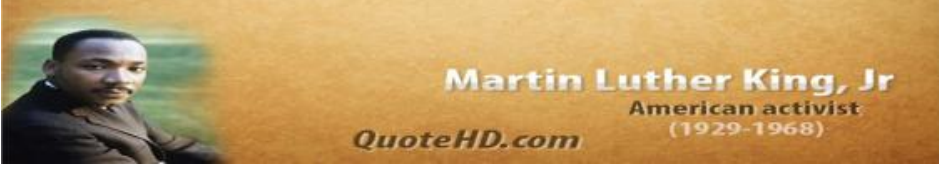

Figure $3^{6}$ - Darkness as hate

Our hypothesis, thus, is that, in language, this conceptual transfer confers on a considerable number of metaphorical expressions with 'black' and 'dark' the same negativity, which would explain the evaluative character of 'black metaphors'. This claim seems to be in line with what Guimarães (2005) argues about the connotative dimension of colour terms: by incorporating positive or negative values to colours, you can transfer these values to particular situations, information, facts, people or entities (political parties, business, social spheres, etc.) identified with these colours. What this paper aims at exploring is precisely the potential of concrete domains such as night/ darkness, in their metonymic relationship with the black colour, to confer a negative value on a given abstract concept.

\section{Literal uses of darkness-related terms in biblical texts}

The methodological procedures followed to 
explore the hypothesis which guided the present investigation were the following:

1- an electronic search, in the corpus (in Portuguese), for passages containing the following words: escuridão, trevas (darkness), (preto, negro) (black), sombra (shadow), noite (night), as well as their derivational lexemes, all belonging to the semantic field of "darkness";

2- sorting out literal from non-literal uses of these words in the corpus, through M.I.P. (Metaphorical Identification Procedure, Pragglejaz Group, 2007);

3- an interpretative analysis of the overall scenario depicted in the passages/narratives in which the terms are used in their literal sense;

4- identification of the metaphorical uses of the same expressions and of the specificities of the target domains ('bad' as: evil, sin, ignorance, death, punishment, fear etc.).

Table 1 shows the total number of occurrences of the five most frequent terms, among the ones used in the word search, as indicated in Procedure 1 above. The frequency of the other words was either too low or inexistent, thus their absence in the table. The frequency, in the corpus, of the literal and the metaphorical uses (identified through M.I.P.) of these five words is also shown. Although it is not our intention to carry out a rigorous quantitative analysis of these first results, it is relevant to stress the evident high frequency of the metaphorical uses of 'darkness' (escuridão and trevas). Night (noite) is used more frequently in its literal sense, often to indicate the period of time when a particular event/narrative takes place.
Table 1: Literal and metaphorical uses of darknessrelated terms in the corpus

\begin{tabular}{|c|c|c|c|}
\hline TERMS & $\begin{array}{c}\text { TOTAL } \\
\text { OCCURRE } \\
\text { NCES }\end{array}$ & $\begin{array}{c}\text { LITERAL } \\
\text { USES }\end{array}$ & $\begin{array}{c}\text { METAPHORICA } \\
\text { L USES }\end{array}$ \\
\hline $\begin{array}{c}\text { Escuridã } \\
0\end{array}$ & 41 & 19 & 22 \\
\hline Noite & 290 & 255 & 35 \\
\hline Sombra & 71 & 46 & 25 \\
\hline Trevas & 88 & 32 & 56 \\
\hline Preto & 7 & 7 & 00 \\
\hline
\end{tabular}

In most corpus-based research on metaphor, the literal uses of the search terms are usually discarded, and only the metaphorical occurrences of the same terms are object of analysis. In this study, however, it was found that a significant number of the literal uses of 'darkness' appeared in passages in which violent, scary, sad, or other negatively evaluated events taking place at night or in dark environments were described.

The biblical text, for example, contains a large number of verses in which the relationship between dark/night and violence/fear/threat is present. According to Hermes (2012), newspaper reports and police reports show that most crimes against life take place at night. There is, therefore, an evident correlation between darkness or dim light and crime. The biblical text contains a considerable number of verses in which the correlation between darkness and violence is present.

Some examples of biblical passages where the literal negativity of darkness, and its association with violence, destruction and death is highlighted are:

(1) In the evening there is fear, and in the morning, they are gone. This is the fate of those who take our goods, and the reward of those who violently take our property for themselves. (Isaiah 17:14)

(2) He who is purposing death gets up before day, so that he may put to death the poor and those in need. (Job 24:14)

(3) And the townsmen of Gibeah came together against me, going round the house on all sides by night; it was their purpose to put me to death, and my servant-wife was

\footnotetext{
${ }^{7}$ Consulta feita em AZEVEDO, F. F. S. Dicionário Analógico da Língua Portuguesa - ideias afins. 2a edição. Rio de Janeiro, Lexicon, 2010.
} 
violently used by them and is dead. (Judges 20:5)

(4) Up! let us go up by night, and send destruction on her great houses. (Jeremiah $6: 5)$

(5) So an opening was made in the wall of the town, and all the men of war went in flight by night through the doorway...(II Kings 25:4)

Darkness, in many cases, then, presents itself as a source of insecurity and fear, since "it makes man subject to a powerlessness of defense against what he can not see, and therefore, can not know" (MESTRE; PINOTTI, 2004, p.29). In addition, the dark prevents people from drawing on action and reaction strategies against the unknown. The vulnerability to which darkness exposes us, according to Guimarães (2000), often paralyzes us. Therefore, besides physical impairment, the dark also has some impact upon human behaviour, since it affects one of the most basic human necessities, which is, according to Maslow (1954), safety.

This sensory-motor experience with darkness, thus, seems to promote negative subjective feelings: "it is very likely that the objective dangers or difficulties experienced in the dark/at night has led humanity, throughout the ages, to fill it with subjective dangers" (DELUMEAU, 2009, p. 142). Some of these possible subjective effects are shown in Figure 4.

Figure 4: Darkness (source domain) and its subjective effects

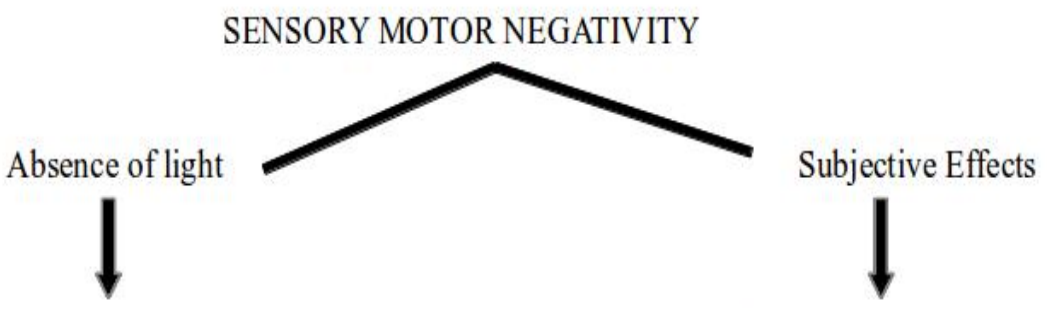

Impossibility of seeing Lack of familiarity, lack of direction Absence of clarity and distinctness More exposure to danger Risk of tripping and falling
It could be verified in the first part of the analysis, then, that the most concrete, sensory-motor experiences with the dark / night seem to trigger negative subjective effects or feelings, whose negativity, in turn, would be mapped upon more abstract concepts, such as evil and sin. Consequently, it is our contention that many of the black metaphors found in the corpus would not represent mere episodic and random comparisons, but expressions that are anchored on conceptual representations which have emerged from concrete negative experiences with the night / dark / darkness.

\section{Metaphorical mappings from the domain of darkness}

The investigation of metaphorical expressions (or vehicles) in the biblical text analysed was based on an identification of black metaphors found in the corpus. This identification was carried out, as mentioned earlier in this paper, through an electronic search for the terms noite/ escuro/ trevas/ sombras/ escuridão, (night, dark, darkness), all semantically related. After sorting out the literal from the metaphorical uses of these terms (Procedure 2), and analysing the latter, one superordinate conceptual metaphor, underlying all the metaphorical expressions, was identified: BAD IS DARKNESS.

This metaphor is explicitly elaborated in a metaphor niche (VEREZA, 2010), in John 1:5:

(6) Darkness has nothing to do with the light or vice versa. They do not mix. What happens when a room is totally dark and you add light? The darkness disappears. What happens when there is a light in the room and you add darkness? The darkness again disappears! Darkness cannot stand before light. Deception cannot stand before the truth! If we have God's words, and we shine them on falsehood, the errors become glaring.

Or in Romans 13:11-13:

(7) Spiritually, darkness is brought on by sin. Darkness gratifies the sinful nature, lulls a person to sleep spiritually, and provides a cover for evil. But his darkness is so thick, man cannot find his way around it, through it, or out of it. The solution to this dilemma will come at "daybreak," "in the morning," "when the day dawns." Even as nothing can prevent the 
coming of dawn, neither can anything prevent the coming of Christ!

In both (6) and (7), the interweaving between source and target domain is quite evident, making the two almost undistinguishable.

In the analysis of the metaphorical uses of dark-related expressions, thus, the main, or most general (superordinate) target domain identified was 'BAD'. However, more specific types (or subclasses) of this target domain have been identified, leading to more specific, but perhaps not so pervasive, conceptual metaphors. These more specific target domains, followed by their respective conceptual metaphors, are discussed in more detail below.

\section{- Bad as ignorance (IGNORANCE IS} DARKNESS)

In the biblical context, the ability and intelligence that a person has to recognize and understand truth are related to the understanding given by God himself. In Psalm 19: 8, it is claimed that "the commandments of the Lord illuminate the eyes", making it clear that the word 'eye' symbolizes the mind and understanding, which led St. Augustine to call wisdom God's "light of minds". Other verses corroborate this interpretation:

(8) the commandment is a lamp, and instruction is the light (Proverbs 6: 23)

(9) the explanation of your words brings light and provides understanding (Psalm 119: 130).

Thus, it might be argued that the conceptual metaphor KNOWLEDGE IS LIGHT is part of a conceptual system entrenched in language since the time of biblical writings. In this context, light would not be any knowledge, but specifically the knowledge of God and of his virtues, which is coherent with another conceptual metaphor identified by Lima (2010), namely TRUTH IS A LIT OBJECT. For this reason, the Bible states that "the teaching of God is a lamp to guide the steps, it is light that illuminates the path" (Psalm 119: 105).
These mappings also seem to be licenced by the conceptual metaphor IGNORANCE/LACK OF KNOWLDGE IS BLINDNESS, semantically negative, which can be considered the inverse of the conceptual metaphor KNOWING IS SEEING. This projection of sensorimotor experiences onto the abstract domain of knowledge has already been identified by Grady (1997), as Lima points out (2012):

From the study of Grady (1997), KNOWING IS SEEING is treated as a primary metaphor. For the author, the experiential motivation of this metaphor is the correlation between visual perception and conscious awareness of information, i.e., the subjective judgment we make of knowledge is conceptualized in terms of sensory experience with sight. (p. 133). The primary metaphor KNOWING IS SEEING involves much more than the correlation between seeing something and being aware of the same thing. The correlation between seeing and knowing mobilizes a wide range of information and experiences related to how we intersubjectively interpret our action in the world and our relationship with people and with ourselves. (LIMA, 2002, p. 161)

Thus, based on the biblical metaphorical coherence, we can say that those who obey the teachings of God 'walk in the light'; those who live contrary to his laws are in 'spiritual darkness', because they reject the light of God himself, and have no knowledge of his truth. Darkness, then, in the biblical text, appears as a metaphor for ignorance: man's ignorance about the divine truths, as it might be observed in the following verse:

(10) The way of the wicked is like deep darkness; they do not know over what they stumble. (Proverbs 4:19)

For better understanding of this biblical passage, it may be interesting to note the verse immediately previous to this one (11), as these two verses together form a contrast which allows a clear analogy: righteous and wicked (target domain); light and dark (source domain):

(11) The path of the just is as the shining light, that shines more and more until it becomes the perfect day. (Proverbs 4:18) 
together with 'shadow', expresses the evil

The just

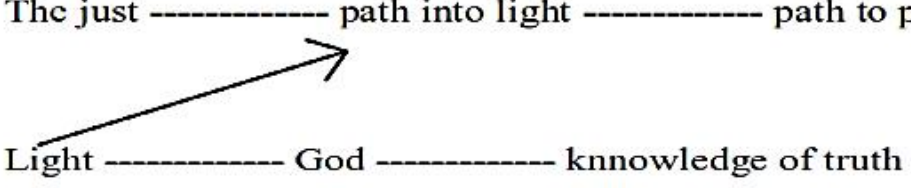

And, conversely:

Figure 6: Analogy: BAD IS DARKNESS

The wicked path into darkness path with stumbles

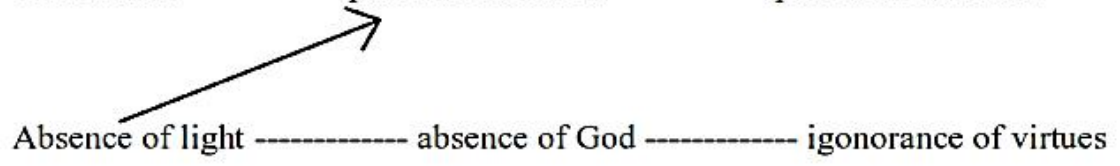

experienced in that context.

(13) And looking at the land, there will be distress and darkness, as well as shadows of anxiety, and they will be driven to darkness. (Isaiah 8:22)

Similar mappings can be observed in (12) and (13), in which darkness / dark also refers to punitive woes received as a result of disobedience to divine orders.

(14) Give glory to the Lord your God, before darkness comes, and before your feet stumble upon the dark mountains; before, while you look for light, he turns it into the shadow of death, and reduces it to darkness. (Jeremiah 13: 16)

- Bad as calamity (CALAMITY

IS DARKNESS)

- Bad as punishment (PUNISHMENT IS DARKNESS)

In several biblical verses, the words 'night', 'dark' and 'darkness' are also used with reference to problems, troubles and afflictions experienced in life as punishment, in a collective or individual perspective, for disobeying divine orders:

(12) Some were living in the dark, distressed and bound with iron chains, because they had rebelled against God orders and rejected his teachings (Psalm 107: 10-11).

By observing the passage as a whole, we can identify the cause (disobedience to divine orders) and the consequences (due punishment) which represent the particular discursive environment in which darkrelated metaphors (night/darkness) are used.

The excerpt (13) refers to a moment of collective punishment that the people of Judah received for disobeying divine commands, so that they were exiled from the Babylonian Empire for 70 years. In addition to the prisoner condition, pain, destruction and desolation also composed the scenario that was installed among the Chaldean people. The conceptualization of the negativity of these experiences is largely constructed by the projection of the negativity experienced in darkness, a term which,
In the book of Job (30: 26), darkness is associated with the sufferings experienced by the character. Despite being a righteous man, committed to ethical and spiritual values and being successful (many children, many possessions and slaves, considered the 'greatest of all those in the East'), Job experienced a great number of tragic fatalities that ruined his life and caused him much suffering and loss. It is in reference to this devastating scenario that we find metaphorical uses of the terms 'dark' and 'darkness' that reinforce the negativity of the context described.

(15) When I expected the right, there came the bad; waiting for light, there came darkness.

(16) I expected happiness, and there came to misfortune; I waited for the light and reached darkness.

Job was surprised by the fatalities that left him without direction, a position of vulnerability before a tragic scenario in which his life was found. These abstract feelings were expressed metaphorically as 'dark'/ 'darkness', as they are, supposedly, similar, in physical and cognitive terms, to those experienced during the night (thus, in the dark).

Job 10: 21-22 
(17) Before I go to the place that will not return, the land of darkness and the shadow of death; dark land, as darkness itself, shadow land of death and without any order, and where the light is as darkness.

(18) Before I go to the place of no return, to the land of shadows and dense darkness, the dark earth as night, land of darkness and chaos, where even the light is darkness.

The metaphorical expressions in (17) and (18) define Job's vision of death, a view that, to a large extent, is still present in our imagination: death as the moment when we close our eyes and everything disappears into darkness. It is this kind of absence of light that prevents man from seeing the life of the living: "enlighten my eyes before I sleep the sleep of death" (Psalm 13: 3).

This metonymical relationship between death and darkness is confirmed in Guimarães (2000):

The colour matching of binarity life-death is the white-black opposition. Death from the very beginning, linked to the unknown and the darkness, is the origin of Western symbology of black. Black, besides being the colour of death and darkness, is the unknown colour that causes fear. (GUIMARÃES, 2000, p. 9192)

- Bad as immorality (IMMORALITY IS DARKNESS)

In the book of Isaiah, the use of the term 'darkness' to refer to immorality is not as explicit as in the other subclasses of 'bad' (target domains) discussed above. This metaphorical association is built throughout the text, and not specifically in verses, though it can be clearly inferred:

(19) And if thou draw out thy soul to the hungry, and satisfy the afflicted soul; then shall thy light rise in obscurity, and thy darkness be as day. (Isaiah 58: 10)

In the larger co-text in which the passage appears, one can find the prophet's advice to people to repent of 'their transgressions and their sins' (1: 1). The sin of which the prophet accuses people refers to the act of seeking God's favour (fasting) only to meet their own needs, without any concern for others. In this sense, the text claims that true spirituality does not lie only in the practice of fasting, but "to loose the bands of impiety, let the oppressed free and shatter every yoke" (58: 6).

"The light rising from obscurity" can be interpreted as the release of men from the $\sin$ of 'impiety' and, therefore, of immorality, which is a general concept embracing many categories of sin, or 'transgressions'. IMMORALITY IS DARKNESS, thus, would be another submetaphor of the superordinate conceptual metaphor BAD IS DARKNESS. In this respect, Lima (2010) states that:

If we associate the concept of good to light and bad to dark, for the sake of cultural and metaphorical consistency, other concepts to which we attribute good and bad value could also be understood in terms of light and dark, creating other conceptual metaphors, for example, MORALITY IS LIGHT and IMMORALITY IS DARKNESS. The relationship between KNOWING IS SEEING and GOOD IS LIGHT / BAD IS DARK is instantiated in the $\mathrm{MCl}$ of knowledge of truth through the juxtaposition of metaphors KNOWING IS TO SEEING THE TRUTH and MORALITY IS LIGHT. (LIMA, 2012, p.169)

\section{- Bad as danger (DANGER IS DARKNESS)}

One of the titles given to Psalm 107, 'God, Savior of all dangers', already gives an indication to what the terms 'darkness' and 'dark' refer to, metaphorically. By observing all verses, one can verify that these metaphors are related to the dangers and difficulties faced by a group of people who was released from the hands of enemies. Thus, in verse 10 (20), the passage refers to the condition of that people; and in verse $14(21,22)$, to their freedom.

(20) Some were living in the dark, in the dark, distressed and bound with iron chains. (Psalms 107: 10)

(21) Such as sit in darkness and the shadow of death, being bound in affliction and iron. (Psalms 107: 14)

(22) He brought them out of darkness, the darkness, and broke in pieces the chains that bound him. (Psalms 107: 14)

The terms 'bound' and 'iron chains' make direct reference to the condition of slavery to which the Jews, when dominated by Egyptian and Babylonian people, were submitted. The figure of the 'shadow of death' indicates a personification of death chasing 
them during the sufferings and hardship they experienced: they were hungry and thirsty and had lost all hope (7: 5) In the midst of this danger, men were terrified (7: 23:26), and feeling very sick; coming very close to death $(7: 18)$.

Considering the dangers they were exposed in order to achieve liberation, it is possible to infer that the terms 'darkness" and 'shadow' allude to the state of complete vulnerability they experienced, during both their captivity and return. The dangers produce physical and psychological effects which are very similar to those produced by darkness: lack of direction, lack of balance, disorientation: "they stumbled, and there was no one to help them" (107: 12); "Go astray, where there is no path" (107: 40); "Walk and stagger like a drunken man" (107: 27).

\section{Conclusive remarks}

The results of the present study highlight the centrality of conceptual mappings from sensorio-motor experiences with darkness onto negatively evaluated abstract domains, as evidenced in the analysis of dark-related metaphorical linguistic expressions ('black metaphors') identified in the biblical text. Thus, as shown in figure 7 , the bodily motivated and negatively perceived experiences with night / darkness are projected upon abstract negative notions, such as ignorance, calamity, immorality, punishment and danger, all of which acquiring semantic coherence through the superordinate conceptual metaphor BAD IS DARKNESS.

Figure 7: Embodied Cognition in the BAD IS DARKNESS metaphor

\begin{tabular}{|c|c|c|}
\hline \multirow{3}{*}{$\begin{array}{l}\text { CONCRETE PLAN } \\
\text { Sigth difficulty } \\
\text { Vulnerability to danger }\end{array}$} & $\begin{array}{l}\text { SPECIFICITIES OF } \\
\text { 'BAD' }\end{array}$ & $\begin{array}{c}\text { SPECIFIC CONCEPTUAL } \\
\text { METAPHORS }\end{array}$ \\
\hline & Bad as ignorance & IGNORANCE IS DARKNESS \\
\hline & Bad as punishment & PUNISHMENT IS DARKNESS \\
\hline \multirow{3}{*}{$\begin{array}{l}\text { Disconfort - } \\
\text { Movement } \\
\text { limitations }\end{array}$} & Bad as calamity & CALAMITY IS DARKNESS \\
\hline & Bad as immorality & IMMORALITY IS DARKNESS \\
\hline & Bad as danger & DANGER IS DARKNESS \\
\hline Desorientation & $\begin{array}{l}\text { Evaluation: dark is } \\
\text { bad }\end{array}$ & $\begin{array}{l}\text { Superordinate conceptual } \\
\text { metaphor:BAD IS DARKNESS }\end{array}$ \\
\hline
\end{tabular}

The hypothesis presented in the introduction of this paper, therefore, seems to have been corroborated by the research findings. The structures of our conceptual system are directly connected with the way our body reacts to particular concrete experiences. Despite the unconscious and often nondeliberate (STEEN, 2011) nature of these conceptual projections, our language materializes them through the presence of metaphorical linguistic markers. It is mostly by the means of the observation of this linguistic evidence that some light might be shed upon the nature of conceptual representations. This seems to be at the core of Conceptual Metaphor Theory, the paradigm shift in metaphor studies introduced by Lakoff and Johnson, in 1980, which was largely inspired by Reddy's study on the Conduit Metaphor (REDDY, 1993).

Finally, it is important to note that the questioning of the strictly ideological explanation of black metaphors does not in any way imply the rejection of culture and ideology as motivating metaphorical forces. The fact that this study has not been extended to the field of ideology might be seen as a possible limitation. However, the research object has been narrowed down so that it could acquire analytical consistency and fit the aims of the investigation, thus enabling the exploration of the guiding hypothesis. However, the ideological dimension of black metaphors, particularly those which can be observed in more recent corpora (MENDES, 2016), and the way it articulates with the sensorimotor domain of experience, resulting in a possible non-dichotomical approach to cognition, stands as a promising development for future investigations, within the principles of what is today known as Critical Metaphor Analysis (CHARTRIZBLACK, 2005; 2006). 


\section{References}

BÍBLIA. Português. Bíblia Sagrada. 2. ed. rev. São Paulo: Vida Nova, 1995.

Português. Bíblia sagrada. Tradução de João Ferreira de Almeida. Ed. rev. e corrigida. Rio de Janeiro: Sociedade Bíblica do Brasil, 2003.

Português. Bíblia de estudo: nova tradução na linguagem de hoje. Barueri: Sociedade Bíblica do Brasil, 2005.

CHARTERIS-BLACK, Jonathan. Corpus approach to critical metaphor analysis. New York: Palgrave, 2004.

Politicians and rhetoric: the persuasive power of metaphor, New York: Palgrave, 2005.

DELUMEAU, Jean. História do medo no ocidente 1300-1800: uma cidade sitiada. São Paulo: Companhia das Letras, 2009, p. 142.

FELTES, Heloísa Pedroso de Moraes. Semântica Cognitiva: ilhas, pontes e teias. Porto Alegre: Edipucrs, 2007.

GRADY, Joseph. Foundations of meaning: primary metaphors and primary scenes. Berkely, US: University of California Press, 1997.

GUIMARÃES, Luciano. A cor como informação: a construção biofísica, lingüística e cultural da simbologia das cores. 2 ed. São Paulo: Annablume, 2000. p.2. p.15.

HERMES, Ivênio. A insegurança da noite. Carta Potiguar, Natal, 2012. Disponível em: <http://www.cartapotiguar.com.br/2012/05/11/ainseguranca-na-noite/>.

JOHNSON, Mark. The body in the mind. Chicago: University of Chicago Press, 1990.

KITTEL, Gerhard; FRIEDRICH, Gerhard. Theological dictionary of the new testament (Volume VII). New York: William B. Eerdmans Publishing Company, 1971

LAKOFF, George; JOHNSON, Mark. Metaphors we live by. Chicago, US / Londres, UK: The University of Chicago Press, 1980.

Philosophy in the flesh: The embodied mind and its challenge to western thought. Nova York, US: Basic Books, 1999, p.4.

Metáforas da vida cotidiana. Tradução do Grupo de Estudos da Indeterminação e da Metáfora. São Paulo: Educ / Campinas: Mercado de Letras, 2002

LIMA, Carmen. O conhecimento da verdade e suas bases conceptuais metafóricas. 2010. 204 f. Tese
(Doutorado em Estudos de Linguagem). Instituto de Letras, Universidade Federal Fluminense, Niterói, RJ, 2010.

LIMA, Silvana Maria Calixto. As metáforas da morte na poesia brasileira: um estudo à luz da linguística cognitiva. Letras, Santa Maria, v. 1/2, n. 31, 2012, p. 161

MASLOW AH. Motivación y personalidad. $1^{\text {a }}$ ed. Barcelona: Sagitario; 1954

MENDES, Lucia D. S. O macaco, a banana e o preconceito racial: Um estudo da metáfora no discurso. Dissertação apresentada ao Programa de Pós-graduação em Estudos da Linguagem da Universidade Federal Fluminense, 2016.

MESTRE, Marilza. Medo e memória: emoção e sociabilidade do final do século XX (1950-2000). Interação, Varginha, v. 4, 2002.

MESTRE, Marilza; PINOTTI, Rita de Cássia. As representações sociais e o inconsciente coletivo: um diálogo entre duas linhas teóricas. Revista Eletrônica de Psicologia, Curitiba, n. 4, 2004. Disponível em: http://www.utp.br/psico.utp.online/site4/repres_soci ais.pdf

PAIVA, Vera Lúcia Menezes de Oliveira. Metáforas Negras. In: (Org.). Metáforas do cotidiano. Belo Horizonte: UFMG, 1998. p. 105-119.

PRAGLEJEZ Group. MIP: A Method for identifying metaphorically used words in discourse. Metaphor and Symbol, vol. 22, 2007. p. 1-39.

REDDY, M. J. (1993). The conduit metaphor: a case of frame conflict in our language about language. In A. Ortony (Org.). Metaphor and thought (2a ed). Cambridge: Cambridge University Press.

STEEN, Gerard. What does "really deliberate"mean? Metaphor in the Social World. Vol 1:1. 2011. p. 5356.

VEREZA, Solange. Notas sobre livros: resenha de: LAKOFF, George; JOHNSON, Mark. Philosophy in the flesh: the embodied mind and its challenge to western thought. New York: Basic Books, 1999. D.E.L.T.A., v. 17, n. 1, 2001. p. 169-170

Metáfora e argumentação: uma abordagem cognitivo-discursiva. Linguagem em (Dis)curso, v. 7, n. 3, p. 487-506, 2007.

O lócus da metáfora: linguagem, pensamento e discurso. Cadernos de Letras, Niterói, n. 41, p. 199-212, 2010. 


\section{COMO CITAR ESSE ARTIGO}

VEREZA, Solange Coelho; PUENTE, Raquel Luz. Embodied cognition in 'black metaphors': the BAD IS DARK metaphor in biblical texts. Signo, Santa Cruz do Sul, v. 42, n. 75, dez. 2017. ISSN 1982-2014. Disponível em: <https://online.unisc.br/seer/index.php/signo/article/view/9962>. Acesso em: doi: http://dx.doi.org/10.17058/signo.v42i75.9962. 